\title{
MODEL PEMBELAJARAN KIMIA KONTEKSTUAL BERBASIS LINGKUNGAN UNTUK MENINGKATKAN HASIL BELAJAR DAN KEJUJURAN AKADEMIK SISWA SMP
}

\author{
Sugiarti \\ Ahli Pendidikan Kimia \\ FMIPA Universitas Negeri makassar, Indonesia \\ Email: atisugiarti34@yahoo.co.id
}

\begin{abstract}
Contekstul chemistry learning model based environment (PKKBL) to improve learning outcomes and academic honesty junior high school students. This study aims to determine the steps the development, validity, practicality and effectiveness of the model PKKBL through the measurement of learning outcomes and academic honesty junior high school students. PKKBL models equipped learning tools that help teachers and students make the learning process so that the learning outcomes of chemical and academic honesty students can be better than before. This research is the development of a model refers to the Borg and Gall (1983) that modofied into seven steps. Subject of research is the students of SMPN 30 Makassar VII 6 class. Data collection tool uses observation sheets, questionnaires, worksheets, and achievement test sheet which has been validated. Data analysis techniques performed by descriptive qualitative and quantitative descriptive percentages. The result showed that: (1) PKKBL models can be developed through three stages of development, namely stages: (a) the initial study, (b) a limited test phase, and (c) the testing phase is extended, (2) the model PKKBL which has been developed showing: (a) instruments are valid models (4.3) and reliable (0.85), (b) the device is practically used (1.6) and (c) because the effectiveness may improve learning outcomes $(82,28)$ and the student's academic honesty belonging to adequate category (72.0).
\end{abstract}

Key words: teaching chemical model, contextual, environment, learning outcomes, academic honesty.

\begin{abstract}
ABSTRAK
Model pembelajaran kimia kontekstul berbasis lingkungan (PKKBL) untuk meningkatkan hasil belajar dan kejujuran akademik siswa SMP. Penelitian ini bertujuan untuk mengetahui langkah-langkah pengembangan, kevalidan, kepraktisan dan keefektifan model PKKBL melalui pengukuran hasil belajar dan kejujuran akademik siswa SMP. Model PKKBL di lengkapi perangkat pembelajaran yang membantu guru dan siswa melakukan proses pembelajaran sehingga hasil belajar kimia dan kejujuran akademik siswa dapat lebih baik dari sebelumnya. Penelitian ini merupakan penelitian pengembangan mengacu pada model Borg \& Gall (1983) yang dimodofikasi ke dalam tujuh langkah. Subjek penelitiannya adalah siswa SMP Negeri 30 Makassar kelas VII. Alat pengumpul data menggunakan lembar observasi, angket, LKS, dan lembar tes hasil belajar yang telah divalidasi. Teknik analisis data dilakukan secara deskriptif kualitatif dan deskriptif kuantitatif bentuk persentase. Hasil analisis data menunjukkan bahwa: (1) model PKKBL dapat dikembangkan melalui tiga tahapan pengembangan, yaitu tahap: (a) penelitian awal, (b) tahap uji coba terbatas, dan (c) tahap uji coba di perluas, (2) model PKKBL yang telah dikembangkan menunjukkan: (a) instrumen model bersifat valid $(4,3)$ dan reliabel $(0,85),(b)$ perangkat bersifat praktis digunakan $(1,6)$ dan (c) efektifan sebab dapat meningkatkan hasil belajar (82,28) dan kejujuran akademik siswa kategori cukup $(72,0)$.
\end{abstract}

Kata kunci: Model pembelajaran kimia, kontekstual, lingkungan, hasil belajar, kejujuran akademik. 


\section{PENDAHULUAN}

Proses pembelajaran kimia baik pada tingkat sekolah menengah pertama maupun menengah atas, bahkan di perguruan tinggi, pada umumnya belum menerapkan pembelajaran yang berpusat pada siswa (student center) untuk menggali sendiri pengalaman belajarnya sebagai dasar memperoleh pengetahuan, sehingga siswa cenderung mengalami kesulitan mempelajari kimia apalagi hanya melalui membaca buku paket. Keadaan ini membawa siswa menjadi kurang berminat dengan pelajaran kimia yang dipenuhi dengan simbol-simbol, lambang unsur, dan rumus kimia yang dianggap sangat sulit bagi siswa. Dilain pihak siswa dituntut memperoleh nilai yang memenuhi kriteria minimal (KKM) yang telah ditetapkan setiap sekolah. Siswa yang menganggap dirinya tidak mampu memenuhi KKM tersebut menempuh cara pintas untuk memenuhi tuntutan tersebut dengan melakukan kecurangan dalam ujian seperti menyontek mendapat bantuan jawaban dari luar, atau melihat catatan. Bahkan cara ini sudah menjadi budaya bagi banyak siswa, yang mengakibatkan siswa tidak percaya diri dan kurang mampu bersaing meraih prestasi yang lebih baik.

Kurikulum KTSP merupakan solusi mengantar siswa mencapai KKM yang telah ditetapkan sebab prinsip dasar pembelajaran dan tujuan KTSP yaitu pembelajaran berpusat pada siswa yang memberi kebebasan menggali potensi perkembangan, kebutuhan, dan kepentingan siswa (peserta didik) dan lingkungan (Musclich, 2011:48). Makna pembelajaran yang berarti mengarahkan siswa belajar melalui pengembangan kompetensi sikap (attitude), keterampilan (skill) dan pengetahuan (knowledge) yang dapat dilakukan dalam bentuk belajar kelompok maupun individual. Ketiga kompetensi ini diterapkan secara komprehensif untuk meningkatkan kualitas belajar dan pembelajaran di sekolah atau universitas (Ericson dalam Dennis, et al (2008:2). Hal ini sejalan dengan arah tujuan pembelajaran melalui pendekatan kontekstual berbasis lingkungan mampu memfasilitasinya berdasar pada keadaan lingkungan sekolah dan dukungan guru sebagai mitra terlaksananya pembelajaran. Sebagaimana yang dipertegas oleh (Depdiknas 2006: 6) bahwa kurikulum pelajaran IPA di SMP (Biologi, Fisika, dan Kimia), disamping mengajarkan teori juga melakukan pembelajaran praktek yang bersesuaian.

Hasil survey dan wawancara dengan guru-guru kimia dan siswa terhadap keterlaksanaan pembelajaran kimia di SMP 30 diperoleh informasi bahwa pada pembelajaran kimia belum sesuai amanat KTSP, guru kimia masih membutuhkan masukan untuk menyesuaikan materi pelajaran kimia dengan model pembelajaran yang tepat. Kedua, memiliki keterbatasan waktu dan kesempatan yang dimiliki guru untuk menyusun sendiri buku pegangan guru, buku panduan siswa dan LKS yang selaras dan terstruktur sesuai karakteristik pelajaran kimia dan karakteristik siswa. Ketiga, diakui bahwa sementara waktu masih menitik beratkan hasil belajar dari aspek kognitif produk. Keempat, pemanfaatan sumber dan media belajar dan fasilitas laboratorium IPA yang ada di sekitar sekolah masih bersifat verbal. Kelima, pembelajaran kimia selama ini sebatas dilaksanakan di dalam kelas. Keenam, perangkat yang digunakan guru kimia sama sekali belum dikembangkan sendiri sesuai karakteritik siswa dan materi pelajaran kimia. Ketujuh, hasil belajar kimia siswa secara ratarata masih sangat rendah (35-40\% tuntas), dan penanaman kejujruan akademik belum diterapkan. Hasil observasi kejujuran akademik siswa selama mengerjakan pretes juga sangat rendah (sekitar 20\%) saja. Kejujuran akademik menggambarkan budaya cerdas yang disertai kehidupan yang berkarakter sehingga menimbulkan berbagai kesenjangan dan penyimpangan (Priyatno dan manullang, 2010:37). Oleh karena itu kejujuran akademik merupakan salah satu nilai pendidikan karakter dapat dibangun melalui pengajaran (Zuriah, 2008:5). Aspek kejujuran akademik yang dapat diterapkan pada pelajaran kimia (integrasi) melalui pembiasaan pada proses pembelajaran, yaitu; (1) mengajukan hasil belajar, (2) peduli dalam kerja sama, dan (3) tidak melakukan kecurangan dalam ujian.

Beberapa hasil penelitian seperti: Suastera (1998) dan Sudria (2000) menemukan bahwa pengetahuan konsep-konsep dasar kimia siswa SMP masih sangat rendah. Simanora \& Redhana (2006) menemukan siswa mengalami miskonsepsi tentang kimia karena kesalahan 
dari gurunya. (Deen, 2006) tentang pembelajaran kimia dengan pendekatan kontekstual, dibutuhkan waktu yang lama (2130 tahun) dan kontinyu. Steenberg dan Bradley (2011): "Kajian materi kimia tidak cukup hanya diceramahkan kepada siswa, tetapi membutuhkan kesabaran guru menuntun siswa mengejanya huruf demi huruf untuk penyebutan lambang yang senantiasa berbeda antara lambang dengan nama unsur". Jones dan Barke dalam Steenberg (2011): “... sebagian lagi materi kimia hanya cocok dibelajarkan melalui percobaan untuk meningkatkan kemampuan siswa menemukan konsep melalui hasil ujicoba, Murdock (2006): “ tiga hal utama siswa berperilaku tidak jujur secara akademik, yaitu: tidak mengetahui tujuan belajar, tidak yakin dengan kemampuannya, dan tidak ada sanksi". Zuchdi (2010): ..." pendidikan karakter kategori kejujuran yang efektif adalah menggunakan pendekatan komprehensif dan melibatkan orang tua, serta unsur sekolah yang diintegrasikan ke dalam bidang studi".

Model PKKBL mengaktifkan siswa belajar dan mengembangkan potensi diri siswa menumbuhkan percaya diri untuk membentuk pribadi dan moral yang jujur, mau bekerja sama dengan teman, tidak bersifat individual dan bahkan malu melakukan kecurangan seperti menyontek. Dengan demikian siswa mengetahui kemampuan dirinya sendiri, percaya dengan batas-batas kemampuan yang dimiliki, dan menumbuhkan sikap sosial dalam kerjasama serta toleransi antar teman.

Berdasarkan uraian di atas, penulis menaruh harapan besar untuk mewujudkan hasil belajar dan kejujuran akademik siswa yang lebih baik dengan melakukan kerja sama dengan guru kimia untuk melaksanakan pembelajaran kimia menggunakan model pembelajaran kimia kontekstual berbasis lingkungan (PKKBL) dan merencanakan integrasi kejujuran akademik ke dalam pembelajaran kimia menggunakan perangkat pembelajaran berupa silabus, RPP, buku pegangan guru, buku panduan siswa, dan LKS, yang disusun berdasarkan karakteristik siswa dan mata pelajaran kimia. Sehingga tujuan penelitian ini adalah (1) mengembangkan model pembelajaran kimia kontekstual berbasis lingkungan yang valid, praktis dan efektif atas beberapa tahap, (2) model yang valid, praktis dan efektif dapat meningkatan hasil belajar kimia dan kejujuran akademik siswa SMP.

\section{METODE PENELITIAN}

Jenis penelitian ini adalah penelitian pengembangan yang berlokasi di SMP Negeri 30 Makassar dengan subjek penelitian adalah siswa kelas VII. Model pengembangan mengacu pada model Borg \& Gall (1983) yang terdiri atas 10 langkah. Tetapi dalam penelitian ini dilaksanakan sampai pada tujuh langkah dengan pertimbangan bahwa melalui tujuh langkah telah memperlihatkan hasil yang meningkat berupa instrumen bersifat valid, model bersifat praktis dan efektif. Ketujuh langkah tersebut selanjutnya di bagi menjadi tiga tahap besar sekaligus menjadi salah satu tujuan penelitian, yaitu: Tahap I berupa: penelitian awal (pengumpulan informasi), perencanaan, mengembangkan format awal produk berupa model pembelajaran dan perangkat pembelajaran (RPP, buku guru, buku siswa, LKS, instrumen model dan alat evaluasi). Semua instrumen dan perangkat pembelajaran yang telah disusun, selanjutnya dilakukan validasi dengan cara menyerahkan instrumen dan perangkat tersebut kepada tiga orang validator ahli yang memiliki disiplin ilmu pendidikan dan pendiikan kimia. Dengan kata lain pada tahap I ini dihasilkan draft model awal (I) yang valid dan reliabel berdasarkan hasil validasi ahli.

Tahap II terdiri atas: uji lapangan awal (uji coba terbatas) dan revisi produk utama. Adapun tahapan ini meliputi ujicoba secara terbatas pada satu kelas terhadap 14 siswa bertujuan untuk memperoleh penilaian pertama terhadap evaluasi kualitatif (an initial qualitative evaluation) dari produk yang akan dihasilkan (Borg \& Gall, 1983), yaitu model PKKBL awal. Pada evaluasi ini lebih menekankan pada aspek muatan produk yaitu apakah model dan perangkat yang disusun lebih baik secara kualitatif sehingga bisa diterapkan dan sesuai dengan cakupan materi pelajaran. Tahapan uji coba terbatas ini dilaksanakan oleh peneliti bersama-sama dengan guru kimia kelas VII pada subjek yang lebih kecil menggunakan rancangan model PKKBL yang terdiri dari rancangan perangkat dan instrumen keterlaksanaan dan pengelolaan, observasi ranah afektif, psikomotor, dan kejujuran 
akademik. Pelaksanaan uji coba terbatas sebanyak dua kali pertemuan yang membahas materi penentuan sifat kimia asam, basa, dan garam. Pada akhir setiap petemuan diiringi revisi berdasarkan hasil pengamatan yang penting dalam penyempurnaan model PKKBL. Hasil akhir daripada revisi ini disebut draft model utama (II) yang digunakan pada uji coba diperluas untuk mengetahui kepraktisan dan keefektifan model PKKBL secara operasional.

Tahap III terdiri atas uji lapangan utama (uji diperluas) dan revisi produk secara operasional. Pada tahap ini merupakan tes lapangan utama (main field testing), yang bertujuan untuk menentukan apakah produk yang ingin dihasilkan memenuhi tujuan (the product's objectives) yaitu model PKKBL yang praktis dan efektif sehingga dapat digunakan pada pembelajaran kimia untuk meningkatkan hasil belajar siswa dan kejujuran akademik. Penerapan uji coba diperluas menggunakan model PKKBL awal pada subjek yang lebih banyak yaitu 42 siswa kelas VII SMPN 30 Makassar. Pelaksanaan uji coba diperluas terhadap model awal daripada model PKKBL dan perangkat dilakukan dengan menggunakan frekuensi pertemuan sebanyak empat kali dan menguji cobakan semua instrumen dan perangkat serta alat evaluasi lainnya yang berkaitan. Selama proses pembelajaran (di kelas, di luar kelas dan di laboratorium IPA), observer bersama dengan guru kimia melakukan assessment autentik terutama terhadap kemampuan siswa dalam hal kemampuan afektif dan psikomotor serta kejujuran akademik, serta bahagian dan format model yang masih perlu dilengkapi. Hal ini sangat penting, sebab pada tahap uji coba diperluas diikuti dengan revisi operasional model PKKBL yang menentukan kualitas akhir model PKKBL sekaligus menjadi produk utama penelitian dan pengembangan ini.

Pengumpulan data melalui instrumen observasi, angket dan tes. Semua instrumen di gunakan mengukur kevalidan, kepraktisan dan keefektifan model PKKBL. Data kepraktisan model dikumpulkan melalui observasi menggunakan instrumen keterlaksanaan model, data keefektifan model melalui observasi menggunakan instrumen aktivitas, kemampuan guru mengelola pembelajaran, angket respon siswa terhadap model PKKBL, dan hasil belajar berupa penilaian autentik terhadap afektif dan psikomotorik siswa diperoleh melalui observasi, dan hasil belajar kognitif dikumpul melalui pemberian tes pilihan ganda pada akhir pembelajaran. Kejujuran akademik dikumpulkan melalui observasi.

Teknik analisis data menggunakan analisi deskriptif kualitatif terhadap proses observasi dan analisis deskriptif kuantitatif terhadap hasil observasi dan hasil tes kognitif yaitu untuk mengetahui kepraktisan dan keefektifan model PKKBL. Untuk menentukan kevalidan dan reliabilitas model menggunakan percentage of agreement, dengan formulasi:

\section{Percentage of Agreement $(R)=$
Agreements $(A)$ $\frac{\text { Agreements }(A)}{\text { Disagreements }(D)+\text { Agreements }(A)} \times 100 \%$}

Kriteria lembar pengamatan keterlaksanaan model pembelajaran dikatakan reliabel jika nilai reliabilitasnya $(\mathrm{R}) \geq 0,75$. Kategori keterlaksanaan setiap aspek atau keseluruhan aspek model PKKBL ditetapkan sebagai berikut:

$$
\begin{array}{cc}
1,5 \leq M \leq 2,0 & \text { terlaksana seluruhnya } \\
0,5 \leq M \leq 1,5 & \text { terlaksana sebagian } \\
0,0 \leq M \leq 0,5 & \text { tidak terlaksana } \\
\text { Analisis terhadap keefektifan model }
\end{array}
$$
PKKBL didukung oleh hasil analisis data dari 4 komponen keefektifan, yaitu (1) aktivitas siswa. Apabila sebesar $70 \%$ aktivitas berada pada interval waktu ideal, baik untuk masing-masing pertemuan maupun secara keseluruhan (Hobri, 2009), maka model PKKBL dikatakan efektif. Rumusnya adalah:

PWI $=$

$\frac{\text { Waktu untuk setiap komponen aktivitas Siswa }}{\text { Waktu }} x$ 100\%.

(2) pengelolaan pembelajaran (KG) dengan model PKKBL yang dianalisis secara deskriptif selanjutnya dikonfirmasi dengan interval kategori:

$\mathrm{KG}<1,5 \quad$ berarti sangat rendah

$1,5 \leq \mathrm{KG}<2,5 \quad$ berarti rendah

$2,5 \leq \mathrm{KG}<3,5$

$3,5 \leq \mathrm{KG}<4,5$

$4,5 \leq \mathrm{KG}$

berarti cukup/sedang berarti tinggi berarti sangat tinggi

(3) respon siswa terhadap pembelajaran model PKKBL, dan (4) hasil belajar siswa dan 
kejujuran akdemik. dianalisis melalui skala kategori hasil pengamatan dan keefektifan model dianalisis melalui hasil pengamatan dan perhitungan $N$-Gain dengan rumus:

$$
\begin{aligned}
& N-\text { Gain }=\frac{\text { nilai posttest-nilai pretest }}{\text { nilai maksimun-nilai pretest }} \\
& \text { dengan skala kategori }
\end{aligned}
$$

$$
\begin{array}{ll}
\text { g-tinggi } & \text { Nilai }(<\mathrm{g}\rangle) \geq 0,7 \\
\text { g-sedang } & \text { Nilai } 0,3 \leq(<\mathrm{g}>)<0,7 \\
\text { g-rendah } & \text { Nilai }(\langle\mathrm{g}\rangle)<0,3
\end{array}
$$

\section{HASIL DAN PEMBAHASAN}

\section{Hasil}

Hasil pengembangan model PKKBL diperoleh melalui tiga tahapan, yaitu: (1) tahap penelitian awal dan pengumpulan informasi, perencanaan, dan mengembangkan format awal, (2) tahap uji lapangan awal (uji coba terbatas) dan revisi produk utama, (3) Uji lapangan utama (uji lebih luas) dan revisi produk secara operasional.

Hasil kegiatan dalam pengembangan model PKKBL di atas, diperoleh tiga jenis hasil utama, yaitu: (1) hasil penyusunan draft model PKKBL, (2) hasil perencanaan model PKKBL beserta perangkat pembelajaran dan, (3) hasil pengembangan instrumen. Ketiga hasil pengembangan ini kemudian divalidasi oleh tiga validator ahli dalam bidang ilmu

\begin{tabular}{|c|c|c|c|}
\hline No. & Nama Instrumen & Validitas & Ket. \\
\hline 1. & Instrumen penilaian model PKKBL & 4,3 & SV \\
\hline 2. & Instrumen penilaian RPP & 4,5 & SV \\
\hline 3. & Instrumen penilaian buku guru & 4,9 & SV \\
\hline 4. & Instrumen penilaian buku siswa & 4,9 & SV \\
\hline 5. & Instrumen penilaian LKS & 4,9 & SV \\
\hline 6. & Instrumen penilaian assesmen pilihan ganda & 5,0 & SV \\
\hline 7. & Instrumen penilaian keterlaksanaan model PKKBL & 4,3 & SV \\
\hline 8. & Instrumen penilaian pengelolaan pembelajaran & 4,4 & SV \\
\hline 9. & Instrumen penilaian aktivitas siswa & 4,3 & SV \\
\hline 10. & $\begin{array}{l}\text { Instrumen penilaian respon guru terhadap model pembelajaran } \\
\text { PKKBL }\end{array}$ & 4,8 & SV \\
\hline 11. & Instrumen penilaian respon guru terhadap buku guru & 4,7 & SV \\
\hline 12. & Instrumen penilaian respon guru terhadap buku panduan siswa & 4,4 & SV \\
\hline 13. & Instrumen penilaian respon guru terhadap LKS & 4,6 & SV \\
\hline 14. & $\begin{array}{l}\text { Instrumen penilaian respon siswa terhadap model } \\
\text { pembelajaran PKKBL }\end{array}$ & 4,7 & SV \\
\hline 15. & Instrumen penilaian respon siswa terhadap buku siswa & 4,8 & SV \\
\hline 16. & Instrumen penilaian respon siswa terhadap LKS & 4.8 & SV \\
\hline
\end{tabular}
pendidikan dan ilmu pendidikan kimia. Hasil validasi perangkat dan instrumen sebagaimana pada Tabel 1.

Tabel 1 Ringkasan Hasil Validasi Instrumen Penelitian

Hasil validasi instrumen model PKKBL diperoleh rata-rata sebesar 4.7 dengan nilai percentage of agreement yang diperoleh sebesar 0,78 yang berarti instrumen dan perangkat model PKKBL termasuk valid dan reliabel sehingga sudah dapat digunakan untuk melakukan uji coba terbatas. Lembar Penilaian yang digunakan sudah divalidasi oleh tiga orang pakar dan praktisi. Hasil analisis terhadap instrumen tersebut menunjukkan bahwa semua instrumen dinyatakan valid sesuai dengan kriteria kevalidan $(4,2 \leq \bar{V} \leq 5,0)$.

Namun demikian masih terdapat saran dari validator terhadap buku pegangan guru dan siswa berupa hurupnya diperbesar, gambargambar dalam buku diperbesar dan warnanya diperjelas sesuai dengan warna asli. Saran lain untuk sintaks disarankan mencantumkan secara 
operasional lingkungan pembelajaran yang dimaksud yaitu lingkungan kelas, di luar kelas dan di laboratorium IPA. Banyaknya kegiatan pada LKS disarankan mengurangi jumlah kegiatan yang terdiri atas 5-6 kegiatan seriap pertemuan menjadi 2-3 kegiatan. Keseluruahn jenis revisi tersebut termasuk revisi kecil dan tidak perlu mengadakan perubahan pada penerapan model PKKBL, sehingga instrumen dapat digunakan sesuai peruntukannya. Dengan demikian instrumen model PKKBL dan perangkat pembelajaran yang telah disusun dapat digunakan untuk mengetahui kepraktisan dan keefektifan model PKKBL dalam meningkatkan hasil belajar dan kejujuran akademik siswa SMP.

Kevalidan, Kepraktisan dan keefektifan model PKKBL. Kevalidan instrumen dan perangkat model PKKBL seperti pada Tabel 1 menunjukkan bahwa draft awal model PKKBL dapat digunakan pada uji coba selanjutnya sehingga kualitas model PKKBL berupa kepraktisan dan keefektifan model PKKBL dapat ditentukan.

Kepraktisan model PKKBL diperoleh melalui pengamatan terhadap keterlaksanaan pembelajaran melalui uji coba terbatas (Tabel 2) dan uji coba diperluas (Tabel 3).

Tabel 2. Hasil Pengamatan Keterlaksanaan Model PKKBL Ujicoba Terbatas

\begin{tabular}{lcccc}
\hline \multirow{2}{*}{ Aspek Pengamatan } & $\begin{array}{c}\text { Rerat } \\
\text { a }\end{array}$ & $\begin{array}{c}\text { Agree } \\
\text { ment }\end{array}$ & Disagreemen & Kategori \\
\hline Sintaks & 1,4 & 9 & 5 & Terlaksana sebagian \\
Sistem sosial & 1,4 & 3 & 11 & Terlaksana sebagian \\
Prinsip reaksi & 1,3 & 3 & 5 & Terlaksana sebagian \\
Sistem pendukung & 1,8 & 17 & 1 & Terlaksana seluruhnya \\
\hline Rerata total & 1,5 & 32 & 22 & Terlaksana sebagian \\
\hline
\end{tabular}

Tabel 3. Hasil Pengamatan Keterlaksanaan Model PKKBL Ujicoba Diperluas

\begin{tabular}{lcccc}
\hline \multicolumn{1}{c}{ Aspek Pengamatan } & Rerata & Agreement & Disagreement & Kategori \\
\hline Sintaks & 1,9 & 24 & 0 & Terlaksana seluruhnya \\
Sistem sosial & 1,7 & 25 & 3 & Terlaksana seluruhnya \\
Prinsip reaksi & 2,0 & 26 & 2 & Terlaksana seluruhnya \\
Sistem pendukung & 1,9 & 36 & 1 & Terlaksana seluruhnya \\
\hline Rerata total & 1,9 & 111 & 6 & Terlaksana seluruhnya \\
\hline
\end{tabular}

Pada uji coba terbatas hanya sistem pendukung yang terlaksana seluruhnya, yang berarti bahwa guru sudah mampu menggunakan perangkat yang dikembangkan terutama RPP. Sebaliknya pada uji coba diperluas keseluruhan aspek terlaksana secara sempurnah. Kenyataan ini dibuktikan selama proses pembelajaran, bahwa semua siswa senang, antusias dan termotivasi mengalami pembelajaran dengan model PKKBL baik pembelajaran di dalam kelas, di luar kelas, terlebih pada saat praktikum di laboratorium. Seringkali siswa tidak mau berhenti bereksperimen sehingga alokasi waktu terasa tidak cukup.

Keefektifan model PKKBL dikatakan efektif bila: (1) aktivitas siswa berada dalam interval waktu ideal (2) kemampuan guru mengelola pembelajaran termasuk dalam kategori tinggi, (3) respon guru dan siswa minimal cukup, dan (4) hasil belajar mencapai kriteria ketuntasan dan kejujuran akademik berada dalam kategori cukup.

Pengamatan aktivitas siswa belajar pada uji coba terbatas tidak dilaksanakan berhubung frekuensi pertemuan hanya dilakukan selama dua kali saja. Tetapi pada uji coba diperluas frekuensi pertemuan lebih banyak dengan membahas tuntas kompetensi dasar yang ditetapkan. Adapun hasil observasi aktivitas siswa pada uji coba diperluas seperti pada Tabel 4. 
Tabel 4. Rata-Rata Persentase Waktu Aktivitas Siswa SMPN 30

\begin{tabular}{|c|c|c|c|c|c|c|}
\hline \multirow{2}{*}{ Kategori } & \multicolumn{4}{|c|}{ Persentase waktu (\%)/pertemuan } & \multirow{2}{*}{$\begin{array}{c}\text { Rata-Rata } \\
\text { Persentase waktu } \\
(\%)\end{array}$} & \multirow{2}{*}{$\begin{array}{c}\text { Interval } \\
\text { toleransi }(\%)\end{array}$} \\
\hline & I & II & III & IV & & \\
\hline 1 & 6.67 & 6.67 & 6.67 & 6.67 & 6.67 & $3.25-9.25$ \\
\hline 2 & 6.67 & 5.33 & 6.67 & 6.67 & 6.34 & $0.00-6.75$ \\
\hline 3 & 8.00 & 6.67 & 6.67 & 8.00 & 7.34 & $5.75-11.75$ \\
\hline 4 & 16.67 & 16.67 & 16.00 & 15.00 & 16.09 & $15.75-21.75$ \\
\hline 5 & 37.33 & 44.00 & 42.00 & 40.00 & 40.83 & $40.75-46.75$ \\
\hline 6 & 9.00 & 11.00 & 10.00 & 13.33 & 10.83 & $9.5-15.5$ \\
\hline 7 & 14.67 & 8.67 & 9.33 & 9.33 & 10.50 & $3.25-9.25$ \\
\hline 8 & 1.33 & 1.33 & 2.67 & 1.33 & 1.67 & $0-3.00$ \\
\hline Jumlah & 100 & 100 & 100 & 100 & 100 & \\
\hline
\end{tabular}

Berdasarkan hasil analisis data aktivitas siswa di atas, dari 8 jenis aktivitas yang diamati, hanya aktivitas menyimpulkan materi yang telah dipelajari (aktivitas ketujuh) yang tidak memenuhi syarat waktu ideal. Siswa masih kesulitan membuat kesimpulan dengan kalimat sendiri, siswa sulit berkonsentrasi dan cenderung tidak percaya diri. Keadaan ini dapat dimaklumi sebab siswa SMP kelas VII masih dalam tahap perkembangan mental yang berada pada posisi transisi antara masa anak-anak dan masa remaja yang membutuhkan pujian, dorongan dan bimbingan serta masih menggunakan bahasa ibu.

Pengamatan pengelolaan pembelajaran didasarkan pada fase-fase sintaks yang telah dirancang dalam RPP. Hasil pengamatan pada uji coba terbatas sebagaimana pada Tabel 5 .

Tabel. 5. Pengelolaan Pembelajaran Model PKKBL pada Uji coba terbatas

\begin{tabular}{clcc}
\hline No & Deskripsi Pengelolaan Pembelajaran & $\begin{array}{c}\text { Rata-rata } \\
\text { Pengamatan }\end{array}$ & Klasifikasi \\
\hline 1 & Fase Menghubungkan & 3.0 & Cukup \\
2 & Fase Pengorganisasian & 3.7 & Tinggi \\
3 & Fase Penggalian Pengalaman & 3.2 & Cukup \\
4 & Fase Penerapan Pengetahuan & 3.2 & Cukup \\
5 & Fase Berpikir Kembali & 3.0 & Cukup \\
6 & Fase Pemanfaatan Pengetahuan & 3.1 & Cukup \\
7 & Suasana Pembelajaran & 3.2 & Cukup \\
\hline \multicolumn{2}{l}{ Rerata Total } & 3.2 & Cukup \\
\hline
\end{tabular}

Kemampuan guru mengelola pembelajaran kimia pada uji coba terbatas berada pada kategori cukup $(2,5 \leq \mathrm{KG}<3,5)$. Hasil ini dapat dimaklumi sebab penerapan ini termasuk uji coba praktisi awal untuk mengkaji kelemahan atau kekurangan instrumen yang telah divalidasi. 
Tabel 6. Pengelolaan Pembelajaran Pada Ujicoba Diperluas

\begin{tabular}{clcl}
\hline $\mathrm{N}$ & Deskripsi Pengelolaan & Rata & Kategori \\
$\mathrm{o}$ & \multicolumn{1}{c}{ Pembelajaran } & -rata & \\
\hline 1 & Fase Relating & 4.3 & Baik \\
2 & Fase Organizing & 4,3 & Baik \\
3 & Fase Experiencing & 4.1 & Baik \\
4 & Fase Applying & 4,1 & Baik \\
5 & Fase Refleksi & 4.0 & Baik \\
6 & Fase Transferring & 4.1 & Baik \\
7 & Suasana Kelas & 4,4 & Baik \\
\hline \multicolumn{2}{r}{ Rerata total } & 4,2 & Baik \\
\hline
\end{tabular}

Jika dikonsultasi dengan harga $\mathrm{KG}$ untuk

harga, $4 \leq \mathrm{KG}<5$ memenuhi kriteria kemampuan guru mengelola pembelajaran dengan kategori baik. Hal ini menunjukkan bahwa pembelajaran dengan kontekstual dapat dibelajarkan oleh guru dengan baik, dan siswa pun menyambut dengan antusias yang dibuktikan dengan sikap dan psikomotorik serta hasil belajar kognitif siswa semakin baik. Karena hasil belajar siswa semakin baik, memberi pengaruh positif terhadap perilaku kejujuran akademik siswa yang semakin meningkat dari kategori sangat kurang (preetes) menjadi kategori cukup (postes). Hal ini terlihat bahwa ketiga aspek kejujuran akademik termasuk kategori cukup. Hasil ini sangat menggembirakan sebab integrasi kejujuran akademik baru pada salah satu materi pelajaran (kimia), tetapi sudah memperlihatkan peningkatan yang berarti.

Respon siswa/guru terhadap penerapan model PKKBL terdiri atas tiga aspek, dapat dilihat pada Tabel 7.

Tabel 7. Respon Siswa Terhadap Pembelajaran, Buku Siswa, dan LKS

\begin{tabular}{clccc}
\hline No & \multicolumn{1}{c}{ Deskripsi } & Pembelajaran & Buku Siswa & LKS \\
\hline 1 & Rata-rata & 4.01 & 4.19 & 4.13 \\
2 & Median & 3.90 & 4.20 & 4.10 \\
3 & Modus & 3.90 & 4.20 & 4.10 \\
4 & Standar Deviasi & 0.42 & 0.35 & 0.46 \\
5 & Nilai minimum & 3.00 & 2,40 & 2.50 \\
6 & Nilai Maksimum & 4.90 & 5.00 & 5.00 \\
7 & Jumlah responden & 42 & 42 & 42 \\
\cline { 2 - 5 }
\end{tabular}

Hasil respon siswa terhadap ketiga perangkat di atas menunjukkan hasil yang termasuk kategori baik. Siswa merasa senang belajar kimia dengan menggunakan ketiga perangkat tersebut dengan dalih bahwa perangkat tersebut saling menunjang dan melengkapi satu sama lain sehingga apa yang dipelajari baik konsep maupun teori dan fakta sangat relevan. Kenyataan ini membuat siswa betah belajar dan memaknai pelajarannya dengan baik.

Hasil belajar yang diperlakukan penilaian autentik terdiri atas empat aspek, yaitu aspek: kognitif produk dan kognitif proses (LKS), kemampuan psikomotorik, dan kemampuan afektif. Hasil penilaian kognitif produk pada ujicoba diperluas secara deskriptif disajikan pada Tabel 8.

Tabel 8. Nilai Statistik Deksriptif Tes Hasil Belajar Siswa

\begin{tabular}{llcc}
\hline No. & \multicolumn{1}{c}{ Statistik } & Pretest & Posttest \\
\hline 1. & Nilai Tertinggi & 82 & 94 \\
2. & Nilai Terendah & 18 & 47 \\
3. & Nilai maksimal & 100 & 100 \\
4. & Nilai rata-rata & 58 & 76 \\
5. & Standar Deviasi & 17,43 & 12,39 \\
\hline
\end{tabular}

Bila nilai pretes dan postes dikelompokkan kemudian dibandingkan berdasarkan kriteria 
ketuntasan hasil belajar siswa, frekuensi dan persentase ketuntasan hasil belajar siswa sebesar $82,28 \%$.

Hasil penilaian kognitif proses (LKS) berada pada kategori cukup yaitu sebesar $87,61 \%$. Penilaian proses berupa kemampuan psikomotorik dan kemampuan afektif berada pada kategori baik dan kategori cukup. Hal ini dapat dilihat pada Tabel 9 dan Tabel 10.

Tabel 9. Kategori Penilaian Kemampuan Psikomotor

\begin{tabular}{llcc}
\hline No & Aspek Pengamatan & $\begin{array}{c}\text { Rata- } \\
\text { rata } \\
(\%)\end{array}$ & Kategori \\
\hline 1 & Persepsi & 84,76 & Baik \\
2 & Kesiapan & 87,30 & Baik \\
3 & Gerakan & 70,74 & Cukup \\
& Terbimbing & & \\
4 & Gerakan Mekanis & 69,06 & Cukup \\
5 & Gerakan respon & 52,38 & Kurang \\
& kompleks baik \\
6 & Penyesuaian pola & 66,09 & Cukup \\
& gerak & & \\
\hline & Rerata total & 71,72 & Cukup \\
\hline
\end{tabular}

Tabel 10. Hasil Pengamatan Kemampuan Afektif

\begin{tabular}{llcc}
\hline No & \multicolumn{1}{c}{$\begin{array}{c}\text { Aspek } \\
\text { Pengamatan }\end{array}$} & $\begin{array}{c}\text { Rata- } \\
\text { rata }\end{array}$ & Kategori \\
\hline 1 & Receiping & 87,81 & Baik \\
2 & Responding & 65,20 & Cukup \\
3 & Evalueing & 71,04 & Cukup \\
4 & Organizing & 73,79 & Cukup \\
5 & Karakterisasi & 80,70 & Baik \\
\hline & Rerata Total & 75,71 & Baik \\
\hline
\end{tabular}

Hasil penilaian kemampuan afektif siswa pada kategori baik (75,71). Keadaan ini diperlihatkan selama proses pembelajaran baik di kelas, di luar kelas mapupun di laboratorium IPA, kebanyakan siswa masih sulit mengerti terutama menjawab dengan benar apa yang ditanyakan, siswa sulit mengatur diri dalam kelompok belajar dan seringkali melakukan kekeliruan dalam menginterpretasi hasil belajar yang diperoleh berdasarkan konsep atau teori. Keadaan ini wajar saja terjadi sebab suatu hasil belajar akan menetap jika muncul hasil belajar baru (bersifat temporer). Keadaan inilah yang Program Pascasarjana Universitas Negeri Makassar akan memodifikasi perilaku dan akhirnya menjadi permanen (Olson, 2009: 4-5).

Hasil analisi data pengamatan kejujuran akademik seperti pada Tabel 11 dengan rerata perolehan sebesar 72, 00 termasuk kategori cukup.

Tabel 11. Hasil Pengamatan Kejujuran

Akademik

\begin{tabular}{|c|c|c|c|}
\hline No & Aspek yang dinilai & $\begin{array}{c}\text { Rata- } \\
\text { rata }\end{array}$ & Kategori \\
\hline 1 & $\begin{array}{ll}\text { Mengajukan } & \text { hasil } \\
\text { belajar } & \text { yang } \\
\text { sebenarnya } & \end{array}$ & 63,38 & Cukup \\
\hline 2 & $\begin{array}{l}\text { Peduli } \\
\text { kerjasama }\end{array}$ & 73,70 & Cukup \\
\hline 3 & $\begin{array}{l}\text { Tidak melekukan } \\
\text { kecurangan dalam } \\
\text { ujian }\end{array}$ & 80,95 & Baik \\
\hline & Rerata total & 72,00 & Cukup \\
\hline
\end{tabular}

Total rata-rata hasil pengamatan kejujuran akademik sebesar 72, 00 berada pada kategori cukup. Aspek kedua (peduli dalam bekerjasama) masih pada kategori cukup. Salah satu item dari aspek ini yaitu mengkritik pendapat teman, siswa mengalami ketakutan dan kelihatan gugup jika ingin mengkritik pendapat teman sebab hal ini tidak biasa terjadi dalam proses pembelajaran sebelumnya.

\section{Pembahasan}

Hasil pengembangan model PKKBL diperoleh melalui tiga tahapan, yaitu: (1) tahap penelitian awal dan pengumpulan informasi, perencanaan, dan mengembangkan format awal, (2) tahap uji lapangan awal (uji coba terbatas) dan revisi produk utama, (3) Uji lapangan utama (uji lebih luas) dan revisi produk secara operasional. Ketiga tahapan ini merupakan hasil modifikasi dari tujuh langkah model Borg \& Gall (1983) yang didasarkan atas kebutuhan penelitian melalui pertimbangan subjek penelitian dan ketercapaian tujuan penelitian yaitu instrumen bersifat valid/reliabel,praktis dan efektif digunakan sehingga hasil belajar dan kejujuran akademik lebih meningkat. 
Hasil validasi instrumen model PKKBL diperoleh rata-rata sebesar $4.7 \quad(4,2 \leq \bar{V} \leq 5,0)$ dengan nilai percentage of agreement sebesar 0,78 , berarti instrumen dan perangkat model PKKBL termasuk valid dan reliabel sehingga sudah dapat digunakan untuk melakukan uji coba terbatas. Lembar Penilaian yang digunakan sudah divalidasi oleh tiga orang pakar dan praktisi. Hasil analisis terhadap instrumen tersebut menunjukkan bahwa semua instrumen dinyatakan valid sesuai dengan kriteria kevalidan. Namun demikian terdapat saran dari validator terhadap buku pegangan guru dan siswa berupa hurupnya diperbesar, gambar-gambar dalam buku diperbesar dan warnanya diperjelas sesuai dengan warna asli. Saran lain untuk sintaks disarankan mencantumkan secara operasional lingkungan pembelajaran yang dimaksud yaitu lingkungan kelas, di luar kelas dan di laboratorium IPA. Kegiatan pada LKS disarankan untuk mengurangi jumlah dari 5-6 kegiatan setiap pertemuan menjadi 2-3 kegiatan. Keseluruahn jenis revisi tersebut termasuk revisi kecil dan tidak perlu mengadakan perubahan pada penerapan model PKKBL, sehingga instrumen dapat digunakan sesuai peruntukannya. Dengan demikian instrumen model PKKBL dan perangkat pembelajaran yang telah disusun dapat digunakan untuk mengetahui kepraktisan dan keefektifan model PKKBL dalam meningkatkan hasil belajar dan kejujuran akademik siswa SMP.

Pada uji coba terbatas hanya sistem pendukung yang terlaksana seluruhnya, yang berarti bahwa guru sudah mampu menggunakan perangkat yang dikembangkan terutama RPP. Sebaliknya pada uji coba diperluas keseluruhan aspek terlaksana secara sempurnah. Kenyataan ini dibuktikan selama proses pembelajaran, bahwa semua siswa senang, antusias dan termotivasi mengalami pembelajaran dengan model PKKBL baik pembelajaran di dalam kelas, di luar kelas, terlebih pada saat praktikum di laboratorium. Seringkali siswa tidak mau berhenti bereksperimen sehingga alokasi waktu terasa tidak cukup.

Kepraktisan model PKKBL pada uji coba terbatas sebagaimana pada Tabel 2 terlihat bahwa hanya sistem pendukung yang terlaksana seluruhnya, yang berarti bahwa guru sudah mampu menggunakan perangkat yang dikembangkan terutama RPP. Sebaliknya pada uji coba diperluas (Tabel 3) keseluruhan aspek terlaksana secara sempurnah. Kenyataan ini dibuktikan selama proses pembelajaran, semua siswa senang, antusias dan termotivasi mengalami pembelajaran dengan model PKKBL baik pembelajaran di dalam kelas, di luar kelas, terlebih pada saat praktikum di laboratorium. Seringkali siswa tidak mau berhenti bereksperimen sehingga alokasi waktu tidak cukup.

Keefektifan model PKKBL ditandai jika tiga dari empat syarat efektif terpenuhi minimal berada pada kategori cukup, yaitu: (1) aktivitas siswa berada dalam interval waktu ideal (2) kemampuan guru mengelola pembelajaran, (3) respon guru dan siswa minimal cukup, dan (4) hasil belajar mencapai kriteria ketuntasan dan kejujuran akademik berada dalam kategori cukup. Berdasarkan Tabel 4 tentang aktivitas siswa, menunjukkan bahwa dari tujuh aktivitas hanya satu yang tidak memenuhi waktu ideal yaitu membuat kesimpulan. Kenyataannya selama proses pembelajaran, siswa masih kesulitan membuat kesimpulan dengan kalimat sendiri, sulit berkonsentrasi dan cenderung tidak percaya diri. Keadaan ini dapat dimaklumi sebab siswa SMP kelas VII masih dalam tahap perkembangan mental yang masih dominan menggunakan bahasa ibu sehingga masih membutuhkan waktu untuk belajar kosa kata yang lebih banyak dan menyusunnya menjadi kalimat yang baku dan benar.

Tabel 5 dan 6 masing-masing tentang kemampuan guru mengelola pembelajaran pada uji coba terbatas dan diperluas berada pada kategori cukup dan baik. Hal ini menunjukkan bahwa guru mampu melaksanakan pembelajaran dengan model PKKBL dengan baik, yang ditandai dengan semua sintaks model PKKBL memenuhi syarat baik pada kedua uji coba. Keberhasilan guru ini ditandai dengan sambutan siswa yang sangat antusias dimana siswa sangat senang belajar, memperhatikan semua unit kegiatan yang ditugaskan melalui kerja sama yang baik 
dengan teman. Tabel 7 tentang respon siswa dan guru terhadap perangkat pembelajaran menunjukkan kategori baik. Siswa merasa senang belajar kimia dengan menggunakan ketiga perangkat tersebut sebab perangkat tersebut saling menunjang dan melengkapi satu sama lain sehingga apa yang dipelajari baik konsep maupun teori dan fakta mudah dipahami karena sangat relevan satu sama lain. Kenyataan ini membuat siswa betah belajar dalam memaknai pelajarannya dengan baik. Hasil analisis mengenai hasil belajar yang meliputi kemampuan kognitif produk mengalami peningkatan dan kemampuan kognitif proses memenuhi ketuntasan kelas. Walaupun dalam proses pembelajaran masih banyak siswa yang sulit mengatur diri dalam kelompok belajar dan seringkali melakukan kekeliruan dalam menginterpretasi hasil belajar yang diperoleh berdasarkan konsep atau teori. Keadaan ini wajar saja terjadi sebab suatu hasil belajar akan menetap jika muncul hasil belajar baru (bersifat temporer). Keadaan ini akan memodifikasi perilaku dan akhirnya menjadi permanen (Olson, 2009: 4-5).

Kemampuan psikomotorik berada pada kategori cukup, sedangkan kemampuan afektif pada kategori baik (Tabel 8,9, dan 10). Keberhasilan siswa dalam pembelajaran ini menunjukkan bahwa model PKKBL dapat menunjang secara total pada tiga aspek utama yang ada pada diri seorang yaitu ingin tahu, respon, dan keterampilan. Khusus pada kemampuan psikomotorik untuk gerakan respon kompleks berada pada kategori kurang baik. Ini sangat wajar terjadi sebab sesungguhnya aspek ini membutuhkan kematangan berpikir dan fokus perhatian tinggi yang belum sesuai dengan perkembangan mental dan gerak siswa SMP kelas VII, namun hal ini dapat diperbaiki jika siswa dilatihkan terus menerus secara berulang. Tabel 11 tentang kejujuran akademik siswa berada pada ketegori cukup. Tetapi pada aspek ketiga (tidak melakukan kecurangan dalam ujian) termasuk kategori baik, sebagai suatu pertanda bahwa sesungguhnya siswa membutuhkan pemahaman yang komprehensif (kognitif, psikomotorik, dan afektif) pada setip pelajaran untuk membangun makna hasil belajar pada diri siswa sehingga siswa benar-benar tahu dan mengerti apa yang mereka sudah paham dan yang belum dipahami. Ketidak tahuan/pahamnya siswa terhadap apa yang telah dipelajari, padahal mereka dituntut lulus memuaskan, membuat siswa mengambil cara cepat dan pintas untuk mencapai kelulusan tersebut dengan cara berbuat curang (tidak jujur) seperti menyontek atau bertanya pada teman saat ujian berlangsung. Melalui pembelajaran dengan model PKKBL, jika diterapkan terus menerus secara tepat dapat meningkatkan hasil belajar kimia dan kejujuran akademik siswa SMP, sehingga secara bertahap siswa mengalami perubahan perilaku secara perlahan dan lebih baik dan menjadi perilaku yang permanen.

\section{SIMPULAN DAN SARAN}

Melalui proses pengembangan model PKKBL yang mengacu pada model pengembangan Borg \& Gall (1983) dapat disimpulkan bahwa: (1) Pengembangan model PKKBL dilaksanakan dengan mengacu pada model Borg \& Gall (1983) melalui tujuh langkah yang disederhanakan menjadi tiga tahapan pengembangan yaitu: (a) tahap penyususnan model PKKBL, (b) tahap uji coba terbatas, dan (3) tahap uji coba diperluas. (2) Kevalidan model PKKBL diperoleh melalui memvalidasi draft model PKKBL. Hasil validasi disebut rancangan model PKKBL yang siap untuk dilakukan uji coba. (3) Kepraktisan model PKKBL diperoleh melalui observasi keterlaksanaan pembelajaran yang berada pada kategori terlaksana seluruhnya. (4) Keefetifan model PKKBL diperoleh berdasarkan empat komponen keefektifan dan telah memenuhi syarat efektif, yaitu: Aktivitas siswa yang diamati telah memenuhi waktu ideal, Guru mampu mengelolaan pembelajaran sesuai sintaks pembelajaran. Respon guru dan siswa terhadap model PKKBL berada pada kategori baik dan baik sekali. Hasil belajar dan kejujuran akademik siswa mengalami peningkatan

Berdasarkan hasil penelitian dan kesimpulan, diajukan beberapa saran antara 
lain: Untuk memperlancar pembelajaran IPA Kimia menggunakan model PKKBL diharapkan ada tenaga pengelola laboratorium dan guru yang mempersiapkan bahan praktikum sebelum siswa memasuki laboratorium. Pembelajaran IPA Kimia dengan model PKKBL diharapkan dapat dijadikan pertimbangan pada pembelajaran IPA Kimia khususnya materi klassifikasi zat untuk meningkatkan pemahaman siswa dan kejujuran akademik. Kepada peneliti lain yang ingin melakukan penelitian lebih lanjut tentang pembelajaran dengan model PKKBL, sebaiknya memilih materi pokok lain dengan memadukan berbagai strategi atau metode pembelajaran sehingga penelitian tentang model PKKBL lebih luas.

\section{DAFTAR RUJUKAN}

Ayuningsih Diah. 2008. Psikologi Perkembangan Anak, Pola Pendidikan Sesuai Karakter dan Kepribadian Anak. Yogyakarta: Pustaka Larasati.

Borg. R Walter and Gall.D Meredith. 1983. Educational Research An Introduction, Fourth Edition. New York \& London. Longman.

Deen-Shamsi, 2006. Contextual Teaching an Learning Practices In The Family and Consumer Sciences Curriculum. Journal of family and Sciences Education, Vol.24, No.I, Spring/Summer, 2006.

Dennis \& Hudson. 2008. Addressing Accoutability via Contextual Teaching and Learning, Online journals 2000-2, (http://www.ed.gov/inits/teachers/exem plarypractices/\#context), Diakses 15 November 2011.

Hobri. 2009. Metodologi Penelitian Pengembangan (Development research) Aplikasi pada Penelitian Pendidikan matematika. Word Editor: Office 2003.

Komalasari Kokom. 2011. Pembelajaran Kontekstual Konsep dan Aplikasi. Bandung: PT Refika Aditama.
Murdock, Tamera B. 2006. Motivational Perspectives on Student Cheating: Toward an Integrated Model of Academic Dishonesty. Article: Department of Psychology University of Missouri-Kansas City. Diakses 14 Juli 2012.

Mushlich Masnur. 2011. KTSP (Kurikulum Tingkat Satuan Pendidikan) DasarDasar Pemahaman dan Pengembangan. Jakarta. Bumu Aksara. 2011. Pendidikan Karakter: Menjawab Tantangan Krisis Multidimensional. Jakarta: Bumi Aksara.

Olson H. Mattehew dan Hergenhahn B.R. 2009. Theories of Learning (Teori Belajar). Edisi Ketujuh. Dialihbahasakan; Tri Wibowo B.S. Jakarta:

Prayitno, Manullang Belferik. 2010. Pendidikan Karakter Dalam Pembangunan Bangsa. Medan: Pascasarjana Universitas Negeri Medan.

Simanora \& Redhana, I W. 2006. Identifikasi Miskonsepsi Guru Kimia pada Pembelajaran Konsep Struktur Atom. Laporan Penelitian DIPA Universitas Pendidikan Ganesha. Lembaga Penelitian Universitas Pendidikan Ganesha.

Steenberg. E. Bradley. J.E. 2011. Symbolic Language In Chemistry- A New Look at an Old Problem. South Afrika: Radmaste Centre, Univeristy of The Witwatersrand.

Suastera, IW dkk. 1998. Pengembangan Strategi Perubahan Konseptual (Conseptual Change) dalam Pembelajaran IPA di Sekolah Lanjutan Tingkat Pertama. Laporan Penelitian. PGSM Dikti. Lembaga Penelitian STKIP Singaraja.

Sudria, IB dkk. 2000. Analisis Pembelajaran Konsep-Konsep Dasar Kimia di SLTP dalam Pengembangan Pembelajaran Konsep-Konsep Dasar Kimia di SLTP. Laporan Penelitian. DIPA STKIP Singaraja. Lembaga Penelitian STKIP Singaraja. 
Zuchdi Darmiyati, dkk. 2010. Pengembangan

Model

Pendidikan

Karakter

Terintegrasi Dalam Pembelajaran

Kimia Lingkungan di Sekolah

Menengah Atas. Laporan Penelitian

Hibah Pasca 2008-2009. Yogyakarta:

Lembaga Penelitian UNY.

Zuriah Nurul, 2008. Pendidikan Moral \& Budi

Pekerti Dalam Perspektif Perubahan.

Jakarta: Bumi Aksara. 